\title{
2. Thinking about justice: a traditional philosophical framework
}

\author{
Simon Rippon, Miklós Zala, Tom Theuns, \\ Sem de Maagt and Bert van den Brink
}

\section{$2.1 \quad$ INTRODUCTION}

This chapter introduces the methods, questions and problems of political philosophy to a general audience with an interest in justice in Europe. ${ }^{1}$ This is necessarily a task of selection. Why highlight certain questions, thinkers and traditions over others? An answer to this question must start with the influence of John Rawls. Contemporary political philosophy was transformed by Rawls's work, especially his A Theory of Justice (1971 [1999]). While many later works we cite are not in what is now sometimes known as the 'Rawlsian tradition', Robert Nozick's (1974) quip still rings true: contemporary political philosophers must either work within the Rawlsian framework or say why they do not. In consequence, we give central attention to the dominant Rawlsian, liberal tradition, and engage alternative approaches (republican, communitarian, critical and so on) primarily through its lens.

The 'European' angle of this volume and its relation to this chapter deserves additional comment. In contemporary political philosophy, the boundaries between continents are generally considered irrelevant to justice: there is no more such a thing as 'European justice' than there is such a thing as 'European mathematics' or 'European physics'. Just as the truths of mathematics are not geographically bounded, most philosophers accept the view that philosophical truths about justice are not bounded by continents. There have of course been influential European thinkers who have contributed to a particular, historically European, philosophical tradition, and have influenced law, political institutions and culture in Europe (and elsewhere). But these European roots of the philosophical tradition are considered, mostly, of purely historical interest. In contrast, the boundaries between nation states, though contested and constructed, are often considered relevant in recent philosophical theorizing about justice - not because each nation state has a peculiar philosophical heritage, but because the nation state has often been considered the basis for shared 
political community, and the distinctive shared rights and obligations of citizenship. The comparatively recent European supranational project, and the rise of a set of a European political and legal institutions that extend beyond national boundaries may, however, bear analogy to nation states in these respects and may have superseded nation states in some ways. (We return to this 'scope of justice' issue in Section 2.4.4 and in Chapter 3, Section 3.6; some of the European legal framework and other aspects of shared European political community are explored in Chapters 5 to 7 , and Chapter 14 of this volume.)

In this chapter, though, our goal is a bird's-eye view of philosophical theorizing about justice. In Section 2.2, we will highlight the characteristically normative focus of philosophical theorizing about justice - a focus on questions not about how things actually are, but about how things ought to be. In Section 2.3 , we discuss what sort of methods can be used to justify normative claims about justice. In Section 2.4, we outline some major philosophical questions about justice, and indicate how competing conceptions of justice arise from different answers to them. Section 2.5 briefly concludes.

\subsection{A 'PHILOSOPHICAL' APPROACH TO JUSTICE: NORMATIVE VERSUS EMPIRICAL QUESTIONS}

Philosophical questions are, broadly speaking, the kinds of questions that cannot be answered by collecting empirical evidence. They are not questions like the following, primarily empirical, ones: Do women carry out a disproportionate share of childcare duties? Is there widespread support for the death penalty? Do most people believe that non-citizens deserve lesser rights than citizens? We could, in principle, answer such questions by collecting and analysing empirical data.

The philosophical questions most relevant to theorizing about justice are normative questions. The question: 'What are individuals due as a matter of justice?' is a normative question. Various empirical facts may be relevant to answering this question (facts about the nature of human beings and their basic needs, for example). But empirical facts alone cannot answer it. The question of what individuals are due as a matter of justice is a question not about how things actually are, but about how things ought to be - and you cannot leap from one to the other. This point is sometimes referred to as the gap between 'is' and 'ought', or alternatively as the fact-value distinction, or as Hume's Law (in reference to Hume 1739-40 [1975], §3.1.1.27). It is the point that you cannot derive any normative conclusion from purely factual claims. If you want to deduce a normative conclusion, you must start with at least one normative claim as a premise in your argument. Normative claims, or 'ought' claims, are claims about things like values, reasons and what one morally ought to do. 
There are 'common sense' normative claims about justice that are widely shared in particular societies. But many questions about justice cannot be answered simply by appealing to common sense. Moreover, common sense might be wrong. So, if we cannot answer normative questions either by collecting empirical evidence or by appealing to common sense, then we must answer them by philosophical reasoning.

\subsection{METHODS}

The primary philosophical method is reasoning and critical reflection. But this phrase is rather vague, encompassing a range of possible approaches. In this section, we outline three main methods used in philosophical theorizing about justice.

\subsubsection{Reflective Equilibrium}

The dominant method in contemporary political philosophy is now reflective equilibrium, after John Rawls (1971 [1999]). We may describe the process of reflective equilibrium in three stages:

1. Begin with one's total set of 'considered judgments' relevant to the domain, including intuitions about particular cases, general principles and theoretical considerations relevant to the choice of principles. (Considered judgments are reasonably confident and stable judgments that have been formed under the sort of conditions that are platitudinally appropriate for forming reliable judgments generally - for example, not under the adverse influence of drugs, emotion, self-interest and so on.)

2. Scrutinize and adjust each of our considered judgments in the light of reflection, of each other, and of any new information, seeking to improve the coherence and plausibility of the set as a whole. Revise considered judgments about general moral principles that conflict with our considered judgments about many particular cases and adopt new principles that explain many such cases, for example. And vice versa: adjust one's considered judgments about particular cases in the light of one's considered judgments about general principles.

3. Continue working back and forth revising one's set of considered judgments, until reaching, in the ideal, a maximally coherent and plausible system of beliefs about justice. The result is the (ideal) state of reflective equilibrium.

The distinctive claim of reflective equilibrium is that justification does not depend on an ultimate foundation of unquestionable moral beliefs, but on 
the coherence between all judgments that are relevant to the issue at hand. Justification, as Rawls writes, 'is a matter of the mutual support of many considerations, of everything fitting together into one coherent view' (1971 [1999], p. 507). When we describe the 'real-world political philosophy' approach for theorizing justice in Europe in Chapter 3, we understand it from the perspective of this Rawlsian tradition. However, adherents of the two alternative methodologies described below may wish to integrate them into the framework we develop.

\subsubsection{Rational Reconstruction}

Another influential methodological approach to justice is known as 'rational reconstruction'. On this approach, the focus is not on our considered judgments, but on the pragmatics and normative presuppositions of rational social interaction. Jürgen Habermas (1981 [1984/7], 1992 [1998]) and his colleague Karl-Otto Apel (1976 [1998]) pursue this method by analysing the necessary, or transcendental, conditions of rational language use. They argue that as rational and communicative agents, human beings must accept some minimal presuppositions of their ability to exchange intelligible political claims. Basically, the idea is that claims to the truth, correctness and integrity of a statement raised in social institutions (including institutions of justice) can be answered with yes-or-no statements, and that in case of disagreement, agents can check the status of such claims by investigating which claims can best be defended with reference to the objective world (truth), the intersubjective world of social norms (correctness) or the subjective world of truthful statements (integrity). This normativity implicit in the pragmatics of everyday rational language use is said to represent an Archimedean point from which we can judge the rational acceptability of all possible claims, including claims about justice. What follows is a political conception of justice to which discursive rules for political communication or deliberation are central, rather than positive principles of justice. It is not the task of political philosophy to formulate substantive principles for the administration of justice, but to help unearth discursive rules for trustworthy political discourse about justice; rules to which human beings are bound as reasonable and rational subjects (Forst 2011).

An important difference between the method of reflective equilibrium and the method of rational reconstruction is that whereas reflective equilibrium starts with our contingent considered judgments about justice, the method of rational reconstruction tries to reconstruct the necessary presuppositions of rational (inter)action as such. The relevance of this distinction is that, whereas Rawls's conclusions in reflective equilibrium may be acceptable only to people who hold a general conception of justice similar to Rawls's, the con- 
clusions of the method of rational reconstruction should be accepted by any possible rational agent.

\subsubsection{Interpretative Methods}

While the method of rational reconstruction is a method of interpretation of the norms that govern our social interaction or our self-understanding as agents, interpretative methods in political theory are generally understood as concerned with articulating inherited normative traditions. Authors such as Charles Taylor (1989), Michael Walzer (1983), Alaisdair MacIntyre (1984) and Axel Honneth $(1995,2014)$ have claimed that practices and theories of justice are derivable neither from a theoretical reflective equilibrium, nor from an understanding of rules for rational social interaction, but from culturally specific standards of practical wisdom embedded in the social and political institutions of particular societies. This approach is indebted to Hegel (1821 [1991]) and to ancient Greek virtue ethics, which stresses the centrality of virtues and communal goods over the entitlements of individuals (Aristotle c. $350 \mathrm{BC}$ [1995], Plato $c$. $380 \mathrm{BC}$ [1992]). The modern communitarian heirs of this tradition emphasize that individual self-determination is possible only within a social context that provides an evaluative framework. Prioritizing the social over the individual, they argue that universalism in ethics must come neither from transcendental presuppositions of agency, nor from a liberal reflective equilibrium from one's individual preferences, but from tradition-bound understandings of the good (Taylor 1989; Honneth 2014).

\subsection{MAJOR QUESTIONS OF JUSTICE}

We now turn to consider predominant questions in the philosophical tradition. Diagrams are used to outline the questions, the major responses and significant sub-questions, then the text offers further discussion. It is not our aim to argue for particular responses here. The aim of this section is rather to provide an orientation for a general audience, offering a synoptic view of the major debates and various concepts that have arisen from them.

The main questions that have dominated the literature on justice in political philosophy are those of 'grounds', 'shape', 'site' and 'scope' of justice. These terms are technical. The question of the grounds of justice concerns where claims of justice come from. Debating the shape of justice means considering both which things are the primary concerns of justice and on what principles they should be arranged. Philosophers may agree on the grounds, but not on the shape, for instance agreeing that claims of justice arise as a result of respect for free and equal persons, but disagreeing whether this means social relations or resources ought to be the primary locus of our concern. Questions of the 
site of justice are about the primary areas of our lives that principles of justice apply to. For instance, some hold that it is the constitutional or 'basic' structure of society that is shaped according to the demands of justice (Rawls 1971 [1999]), while others think that justice also makes demands on the actions of private individuals (Cohen 1997). Finally, questions on the scope of justice ask to whom justice is due - do the primary actors of justice (identified once the site of justice has been fixed) owe the duties of justice (the shape) to all persons, or only some (for example, compatriots)?

\subsubsection{Grounds of Justice}

Perhaps the most general normative question of justice is: What is everyone due? To be 'due' something in this sense means to have a legitimate claim on others. This raises the question: where do these claims of justice come from, or in other words, what are the grounds of claims of justice? Below, we discuss in turn each of the answers illustrated in Figure 2.1.

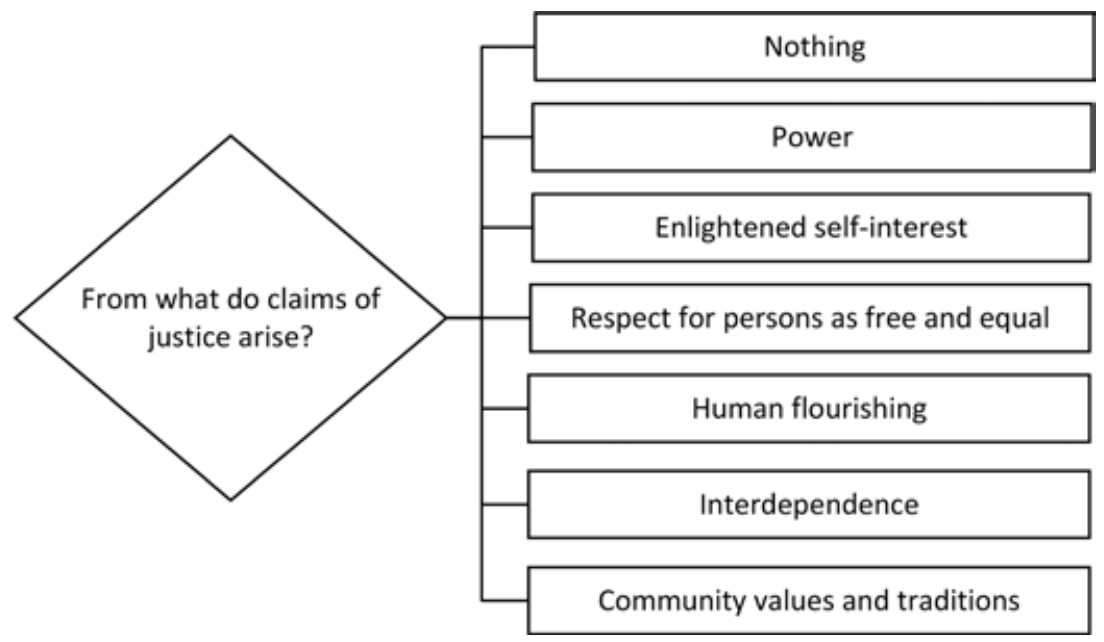

Figure 2.1 Grounds of justice

Discussion of the grounds of justice in philosophy goes back at least as far as Plato's ancient Greek dialogues, the Gorgias (c. 390 BC [1979]) and the Republic (c. 380 BC [1992]). The answer has a bearing on which claims of justice we have, and on whom we have these claims. For example, Plato's character Thrasymachus says that 'justice' is a charade: nothing more than the power of the stronger over the weaker (c. 390 BC [1979]), 338c2-3). If we accept his scepticism, we may decide that there are no legitimate claims 
of justice at all. Plato's character Callicles, who influenced Nietzsche (1886 [1990]), urges that an elite few have a natural right to rule over the many and to appropriate their power and possessions due to their strength and superiority (c. 380 BC [1992], 483d-484c).

A less sceptical answer is found in the contractarian tradition associated with Thomas Hobbes's Leviathan (1651 [1994]). Contractarians say the claims of justice are a social contract justified by enlightened self-interest. Hobbes imagined a hypothetical 'state of nature' prior to government in which there was no security, since anyone's life or resources could be taken by others at any time. In such circumstances, pre-emptive attacks on others may be a rational means of self-defence; the unfortunate consequence of this being that life for everyone would be, as Hobbes famously described, 'solitary, poor, nasty, brutish and short' (1651 [1994], XIII. 9). Self-interest thus demands that individuals in the state of nature form a mutual contract, surrendering their power to a Sovereign capable of enforcing order. While Hobbes himself envisages an inegalitarian and undemocratic state, later contractarians such as Gauthier (1986) have argued for self-interested foundations for democratic, egalitarian systems of justice.

Another answer based in enlightened self-interest is found in the republican tradition (Machiavelli 1532 1989]; Pettit 1997; Skinner 1998). According to republicans, claims of justice arise from our interest in living under institutions that enable us to exercise individual and collective agency, while protecting us from arbitrary invasions of our liberty either by fellow citizens or by the government.

A related answer sees justice as a social contract justified not by self-interest, but by fundamental moral respect for others. The liberal contractualist tradition, rooted in the Enlightenment conception of persons as free and equal represented by Immanuel Kant (1785 [1983]), is particularly associated with the work of John Rawls and T.M. Scanlon (1998). Rawls develops a theory of justice grounded in a moral conception of the person which understands persons as 'self-authenticating sources of valid claims' (Rawls 2003, p. 23). His theory does not specify how persons should live, but only tries to secure the conditions under which persons can lead their lives independently. Rawls has claimed that his understanding of citizenship combines, in Benjamin Constant's words, the 'liberty of the moderns', conceived around civil liberties warranted through individual rights, and the 'liberty of the ancients', or participatory liberties in republican institutions (Constant 1819 [1988]; Rawls 1993).

Philosophical anarchists claim that the fundamental freedom and equality of persons makes state coercion impermissible, so that legitimate political authority is impossible (Wolff 1970). Some who try to defend political authority against the anarchist challenge argue that legitimate political authority is possible based on the consent of the governed (Estlund 2005), or on the idea 
of fair play (Klosko 1987). Others argue that our voluntary associations within a political community ground the legitimacy of political authority (Dworkin 2011).

Social contract theories diverge on whether the contract in question is supposed to be actual or hypothetical (that is, a contract we would or should have signed if we had been given the opportunity). If the social contract is an actual contract, then plausibly we should obey its terms because we have consented to them. But, of course, there was no historical moment when we all explicitly agreed to live under a given system of laws. On the other hand, a merely hypothetical contract is imaginary, and thus, according to critics, no contract at all.

One possible response to this dilemma is to follow a tradition going back to Plato (c. $390 \mathrm{BC}$ [1979]), which argues that we give tacit consent to the social contract by living in an ordered state and accepting its benefits. Common sense principles of gratitude (to the state) or fair play - that is, accepting a share of the burdens of a mutually beneficial system - may support the claim that we have a duty to obey a system of law that is basically just, even when it is not to our personal advantage. A democratic political system allows us to express our explicit consent for certain aspects of the coercive state structure, such as the empowerment of particular representatives. Indeed, some theorists argue that, through their democratic, political liberties, citizens can guard and help formulate the laws that set the just terms under which they can exercise their individual liberties. According to this view, the exercise of active and deliberative citizenship in historically grown institutions under the rule of law - not the imagined theoretical terms of an original contract - is the ultimate source of claims concerning justice (Habermas 1992 [1998]).

A different approach grounds justice in a favoured conception of human flourishing. Certain republicans, going back to Aristotle (c. 350 BC [1995]), argue that being an active citizen in a political community is essential to a flourishing life. In contemporary philosophy, Martha Nussbaum (2001) argues that certain human functional capabilities, such as the capability to live to the end of a natural life, to have good health or to play, are essential to human flourishing. Some claim that flourishing requires autonomy, and that the institutions of a just society would promote the living of sufficiently autonomous lives by society's members (Raz 1986; Honneth 2014). This is different from Rawlsian liberalism, which attempts to remain neutral on questions of human flourishing.

Views such as Raz's and Honneth's are close to the Hegelian argument that our conception of ourselves as free and equal individuals depends on others recognizing us as such (Hegel 1821 [1991]; Honneth 1995). Contemporary theories of the need for recognition and the harms of misrecognition are developed in the work of theorists such as Charles Taylor (1992), Axel Honneth (1995) and Nancy Fraser (1995). Other theories, in the feminist 'ethics of care' 
tradition, emphasize the responsibilities associated with familial and other close relationships over individual liberal rights (Kittay 1999; Held 2006). These theorists, who stress interdependencies, have shown that forms of exclusion from full citizenship underlie many experiences of injustice. The struggle for overcoming these is an important ground of justice itself.

Finally, some political theorists reject altogether the attempt to ground justice in an 'Archimedean point' outside of any existing community, and its traditions and values. Communitarians deny that unencumbered individuals choose their values ex nihilo. They argue that there is no such thing as a self apart from its communal attachments, and that the claims of justice cannot be universal, but must be a matter of interpreting existing social structures, practices and beliefs (Walzer 1983; MacIntyre 1984). This thought leads them to adopt the interpretative method described in Section 2.3. Accordingly, these thinkers tend to be sceptical of large swathes of universal human rights discourse. Critics of these communitarians claim that they illegitimately attempt to deduce how things ought to be from what is accepted by members of a community, failing to sufficiently question the social practices and systems of value that are predominant in particular communities.

\subsubsection{The Shape of Justice}

We now turn to the shape or principles of justice. Almost everyone can agree that political justice is a matter of treating people as equals, though not necessarily identically. The rub comes in working out exactly what it means to treat people as equals, in a just way. Following Rawls (1971 [1999]), we can make a distinction between a 'concept' and a 'conception' of justice. The concept of justice refers to the question that a theory of justice tries to answer - 'What is everyone due?' A conception of justice gives a specific answer to this question, for example in the form of a set of normative principles of justice, or a normative theory. Most people have a concept of justice, but few have a fully-fledged conception. One task of political philosophy is to work out a plausible conception of justice.

It is important to note that justice in political philosophy is often, but not always, conceived in (purely) distributive terms. An ideally just society would then be one in which some set of goods - and perhaps burdens, as well - is distributed in a fair way. To yield a conception of 'distributive justice', a theory needs to tell us which goods (the metric of justice) should be distributed in what way (that is, it needs to identify just distributive principles). This is not a trivial matter, as shown by the many questions that arise on the 'distribution of goods' branch of Figure 2.2 (pp. 26-7).

There are different proposals for the metric of distributive justice. Perhaps most people think of distributive justice primarily as fair distribution of mate- 
rial goods and services. Many philosophers argue this leaves out other important things. For utilitarians, the metric of justice is 'utility', or pleasure or welfare, which they often consider the only thing good in itself (Bentham 1789 [1970]; Mill 1861 [1991]). Other theorists consider justice to be primarily concerned not with outcomes like welfare, but with distribution of opportunities. For libertarians or classical liberals, the metric may be negative freedoms; that is, the absence of constraints or interference by others (Berlin 1958 [2002]). John Rawls's (1971 [1991]) liberal theory treats as metrics both basic liberties (freedom of thought, of association, to vote, to hold political office and so on) and other so-called 'primary goods'. Primary goods are all-purpose resources for leading your preferred plan of life, such as basic liberties, opportunities, income and wealth and the social bases of self-respect. More recently, Amartya Sen (1990) and Martha Nussbaum (2001) have argued that the metric of justice should rather be 'capabilities': real opportunities to do and to be what individuals have reason to value. An argument for this is that individuals have different abilities to transform resources into things they value. For instance, moving around is easy for some, whereas others need a wheelchair. What is important for justice, according to proponents of the capability approach, is that we have sufficient capability (in this case mobility), not that we have some share of resources, liberties or welfare.

The second component of a distributive theory of justice is a distributive principle. Since utilitarians believe we ought to maximize utility, they adopt a maximizing distributive principle: welfare should be distributed in whatever way maximizes the aggregate welfare. A maximizing distributive rule indeed treats people equally in one way: no unit of welfare counts more or less than any other, no matter whom it belongs to. But one might doubt that this kind of equal treatment embodies justice, as it allows extreme inequalities in welfare. Can a society really be just if some are left very badly off in order to enable a slightly greater benefit to flow to others who are already extremely well off? Such considerations lead others to adopt different views.

One such view is strict egalitarianism, according to which everyone should get the same amount (Nielsen 1979). A worry about this view is that maintaining it over time would require constant, coercive interference, since even if you start off with an equal pattern, people are unlikely to want to use their resources in a way that maintains strict equality. Another is that a strictly egalitarian distribution may be inefficient; leaving everyone worse off collectively than they might otherwise be if some inequalities were permitted. An alternative proposal that may be less susceptible to these objections is prioritarianism, according to which inequalities are permitted, as long as they benefit the worst off group (Rawls 1971 [1999]; Parfit 1997). Another oft-defended distributive rule is sufficientarianism, according to which everyone should have enough, or sufficient, to meet a basic threshold for a good life. According to this view, 


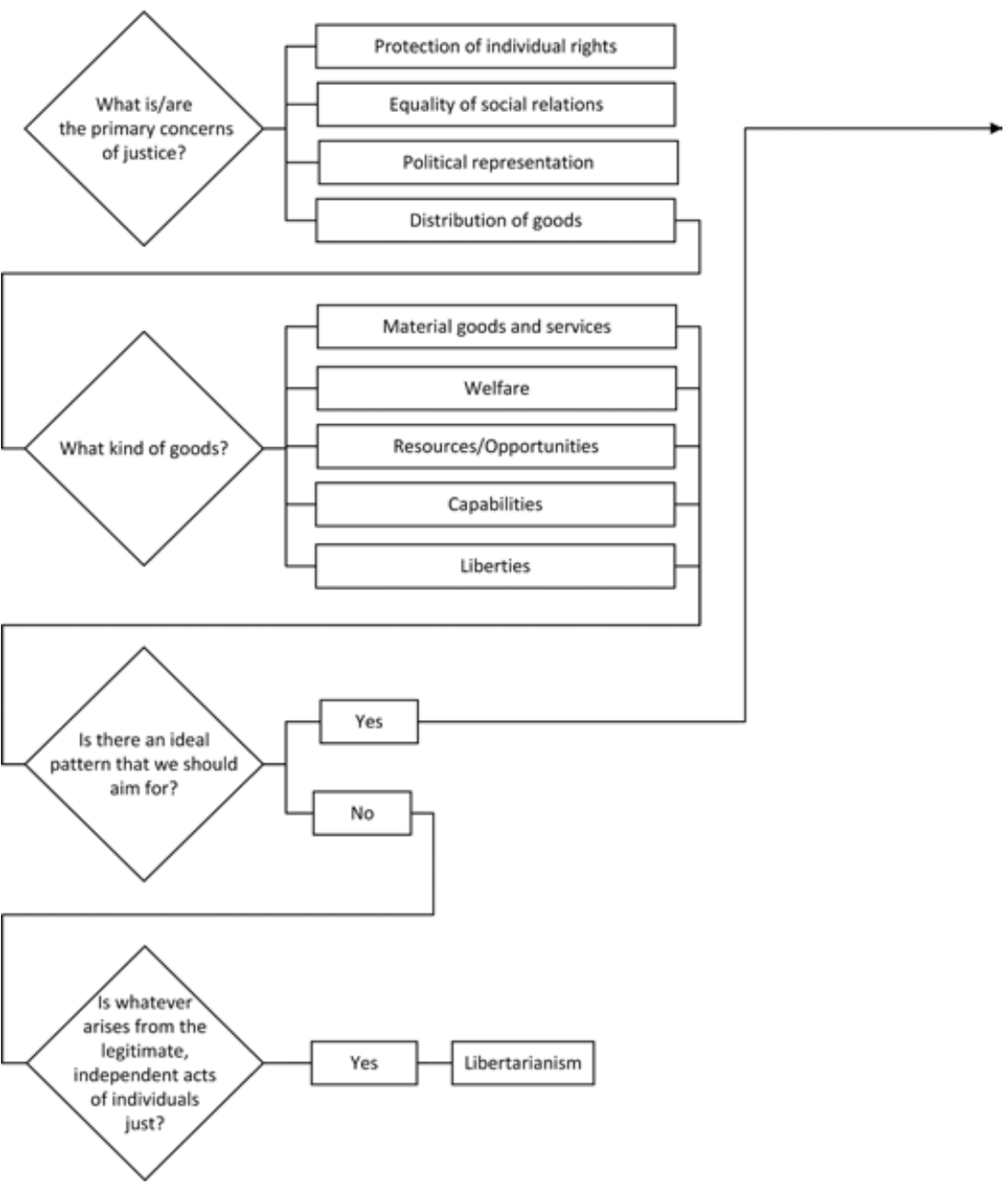

Figure 2.2a The shape of justice

if everyone were sufficiently well off, inequalities wouldn't matter from the perspective of justice (Raz 1986; Frankfurt 1987).

A theory of justice can include more than one of these distributive principles in combination with different metrics, as shown in Figure 2.2. An interesting example of such a combination is found in John Rawls's influential theory of 


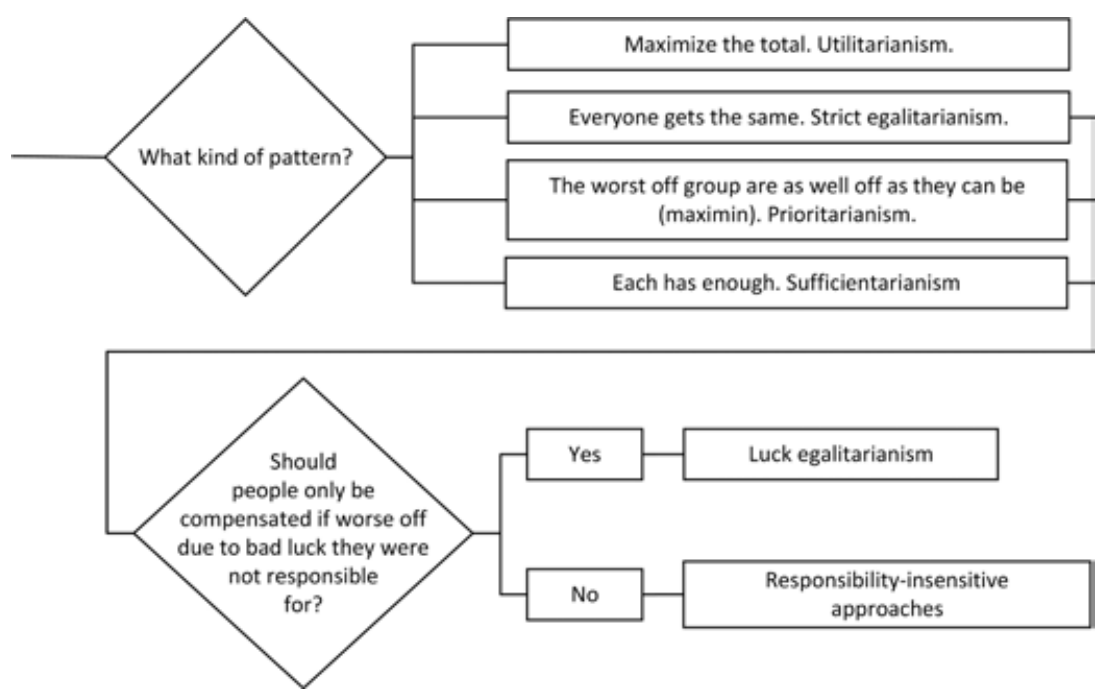

Figure 2.2b The shape of justice (continued)

justice, which gives two basic principles for the regulation of social institutions, with the first principle prioritized over the second. In Rawls's words:

FIRST PRINCIPLE [the 'principle of equal basic liberties']

Each person is to have an equal right to the most extensive total system of equal basic liberties compatible with a similar system of liberty for all.

\section{SECOND PRINCIPLE}

Social and economic inequalities are to be arranged so that they are both:

a) to the greatest benefit of the least advantaged, consistent with the just savings principle, [the 'difference principle'] and

b) attached to offices and positions open to all under conditions of fair equality of opportunity [the 'principle of equality of opportunity']. (Rawls 1971 [1999], p. 266)

Some critics have argued that Rawls's theory is insufficiently responsibility sensitive. If some people deserve more than others due to their effort or choices, then an inequality between them, even if it violates the difference principle, may not be unjust. So, an additional concern of many theories of distributive justice is to specify when departures from the otherwise favoured distributive pattern can be justified.

Luck egalitarians believe that justice requires us to neutralize the effects of bad luck on outcomes but allows for unequal distributions resulting from choice or other things we are responsible for (Arneson 1989; Cohen 1989). 
Many luck egalitarians also distinguish between the effects of unchosen 'brute luck', the effects of which they believe should be neutralized, and the results of calculated gambles, or 'option luck', the effects of which should not (Dworkin 1981). In practice, however, the effect of choice and luck on outcomes is intermingled and it is difficult to draw a principled line between them. As Rawls (1971 [1999]) noted, one's natural capacities, one's environment, and even one's propensity to exert effort, depend on natural and social luck.

It has so far been assumed that a distributive principle will favour a particular distributive pattern, such as strict equality or the sufficientarian principle. The libertarian Robert Nozick (1974) notably denied this. According to Nozick, a distribution of property would be just not because it represents some favoured pattern, but because it has an appropriate history. According to Nozick's 'entitlement theory', any distribution of property is just if it is the product of just initial acquisition followed by any number of just transfers. Suppose, for example, that you can justly acquire pieces of unowned land by cultivating them, and that you can justly transfer them by voluntary exchange. Then any pattern of distribution of land is just, provided it came about by voluntary exchanges of land that was initially acquired by cultivating it. Moreover, Nozick argues it would be unjust for a state or anyone else to then forcibly interfere to realize some favoured pattern, since this would violate individuals' existing entitlements. This theory has its roots in the work of John Locke (1689 [1988]), who considered justice to consist in respect for every person's natural, absolute rights to self-ownership, ownership of private property and freedom from harm. Although negative views of this kind can be considered theories of distributive justice (and thus as choice-points on the 'distribution of goods' branch of Figure 2.2), it might make more sense to consider them as seeing justice as concerned with something other than the distribution of goods: namely, the protection of individual rights (shown on the first branch of Figure 2.2).

Turning now to the second branch of Figure 2.2, relational egalitarians claim that what is fundamental to a just society is equality of social relations, so that distribution of goods has at most a derivative or secondary importance (Anderson 1999). Therefore, a quantitative ideal of equality that focuses on the distribution of certain goods is mistaken, or at least incomplete (Young 1990). Relational egalitarians have criticized three kinds of social hierarchies: (1) hierarchies of domination and command, (2) hierarchies of standing, and (3) hierarchies of esteem (Anderson 2012). To be dominated by another is to be subject to their arbitrary will. Even if someone is not in fact coercively interfering with my choices, I am under a condition of domination if others could do so should they choose (a paradigmatic example of such domination is a slave under the power of a well-disposed master). Egalitarians also object to social systems with hierarchies of standing where 'those of higher rank enjoy 
greater rights, privileges, opportunities, or benefits than their social inferiors' (Anderson 2012, p. 43). Equality of esteem requires a society where no individual need occupy an inferior role associated with feelings such as disgust, contempt or fear (Anderson 2012; see also Wolff 1998).

In the Hegelian tradition, theories based on recognition are also relational egalitarian, emphasizing our dependence on the affirmation of others (Taylor 1992; Fraser 1995; Honneth 1995). Theories of recognition, Honneth's in particular, have separated principled forms of equal respect in morality and law from a meritocratic conception of esteem as related to the execution of social roles in modern society. One reason why people may suffer from lower social standing or face other obstacles is because they belong to minority groups. Multiculturalists argue that to mitigate these problems, states should actively recognize and accommodate such groups, by giving special rights to individual members of these groups (such as the right of turban-wearing Sikhs in many jurisdictions to exemption from motorcycle helmet laws), or by giving the group as such special rights (such as the rights of indigenous populations to self-governance) (Kymlicka 1995).

Turning to the third branch of Figure 2.2, some theorists argue that the fundamental concerns of justice are principles of political participation and voice - that is, of political agency and representation (Habermas 1992 [1998]; Pettit 1997; Skinner 1998; Mouffe 2000). On this view, principles for the distribution of goods of the kind discussed above can only be legitimated through stable politico-legal institutions that lend fair democratic access and voice to the ultimate addressees of questions of justice and injustice: citizens. More practically, there is the question of whether a just political community should incorporate direct or representative democracy. Jean-Jacques Rousseau's The Social Contract (1762 [1997]) argued for the former position, while Edmund Burke (1790 [1987]) and John Stuart Mill (1861 [1991]) famously argued for the latter view.

Just as a theory of justice may include multiple distributive principles and metrics, a theory of justice may consider more than one of the preceding concerns as primary. One such influential view is that of Nancy Fraser (1996, 2008). Her 'tripartite' conception identifies redistribution, recognition and representation as three primary and mutually irreducible concerns of justice, though each necessary for the realization of 'participatory parity' (see also Chapters 1, 3, 4 and 12). She initially developed this view as a reaction to scholars such as Honneth, who she thought mistakenly subsumed distributive claims under recognitive claims. Fraser's view, in contrast, is that recognition and redistribution are mutually irreducible aspects of justice that have broad independent application to addressing real-world injustices: 'virtually all real-world oppressed collectivities ... suffer both maldistribution and misrecognition in forms where each of those injustices has some independent 
weight' (Fraser 1996, p. 22). Over time, Fraser's account expanded to a tripartite view, adding an additional dimension of justice as political representation (2008). Regardless of where one stands on the controversial matter of reducibility, it seems likely that an empirical evaluation of the justice or injustice of states of affairs in any society is likely to require knowledge of (mal)distribution, (mis)recognition, and the (in)adequacy of systems of representation in that context.

\subsubsection{The Site of Justice}

We now consider what kinds of objects (institutions, family life, individual actions and so on) principles of justice apply to - that is, the site of justice. Below, we discuss the three main options illustrated in Figure 2.3.

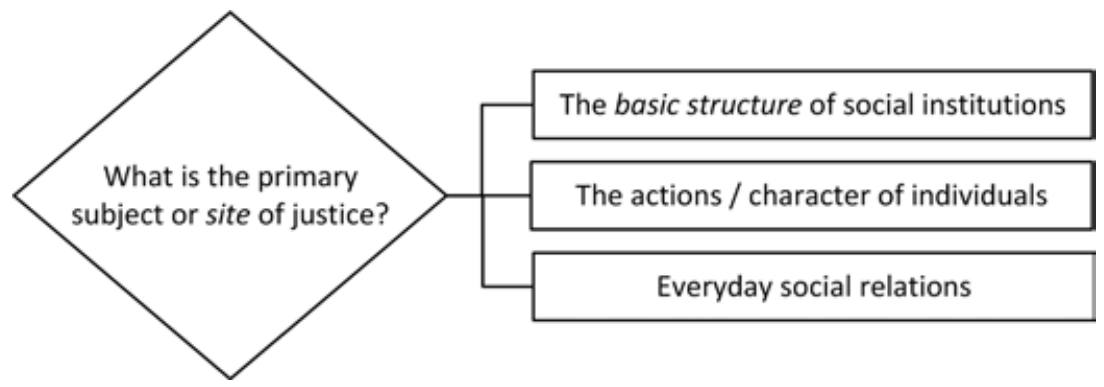

Figure 2.3 The site of justice

A main divide over the site of justice is between theories that consider it sufficient for the existence of a politically just society if principles of justice shape social institutions, and theories that hold that in a just society, principles of justice must shape personal behaviour as well. Rawls (1971 [1999]) held that the principles of justice apply only to the design of the 'basic structure' of society. The basic structure is the system of political and social institutions that determine the fundamental terms of social cooperation, such as the constitution, the system of property rights, the economic structure, and laws regarding familial rights and obligations. G.A. Cohen (1997) criticized Rawls for ignoring unjust power relations and inequalities that can occur due to people's private choices even within a just basic structure. Cohen argued that a just society also requires that people also develop an ethos of justice that guides their individual choices.

The site of justice question also animates feminist critics of mainstream political theory; indeed, Cohen cites the feminist slogan 'the personal is political' in laying out his critique of Rawls (Cohen 1997, p. 3). Feminist theorists 
have unearthed shortcomings of theories of justice in recognizing women as equal members of society. In liberal theory, the private sphere is seen as the site of individual liberty, in which life, liberty and estate are enjoyed (Locke 1689 [1988]). The public political sphere has instrumental value only, as the space in which laws are formulated and rights are secured. As the head of family, men have been understood to represent interests from the private sphere politically, culturally and economically. In classical republican theory, the public, political sphere is seen as the realm in which the ethical goods of civic engagement and deliberation are enjoyed. It was conceptualized as a sphere for (select) male members of the polity, again resulting in the exclusion of women from debates about justice (Aristotle c. 350 BC [1995]). This exclusion of women prevents equal exercise of political rights (Pateman 1989; Okin 1991).

What is at stake here are matters of informal status and standing in liberal-democratic societies that increasingly acknowledge the existence and experience of difference in social relations. Critics have argued that the modern Western concept of citizenship, as defined by an individual's holding of civil, political and social rights, is blind to consequences of this generalized framework for individuals in their situated perspectives (Anderson 1999; Young 1990). Claims for 'differentialist' conceptions of citizenship, which call for a greater acknowledgement of the political relevance of differences with regard to culture, gender, class and race have sprung from these debates. This has led to a greater recognition of the pluralistic character of the democratic public, and to (contested) claims for differential treatment of specific groups in society, for instance through the granting of minority rights in multicultural societies (Kymlicka 1995).

\subsubsection{The Scope of Justice}

We now turn to the scope of justice: the question to whom the principles of justice, and particularly principles of distributive equality, apply. Do they apply only to fellow citizens of a nation state (or perhaps to a supranational federation such as the European Union, as discussed in Chapter 3, Section 3.6), or beyond borders, to humanity in general (Figure 2.4, below)?

Moral cosmopolitans claim that principles of justice have a global scope, applying to people everywhere. Moral cosmopolitans divide among themselves between moderate moral cosmopolitans, who believe our duties to provide assistance to the distant needy are partially mitigated by special duties we have towards our compatriots (Scheffler 2001), and strict moral cosmopolitans, who believe that justice makes no distinction between our compatriots and others (Caney 2005). Both positions contrast with that of anti-cosmopolitans; those who argue that our obligations to compatriots either 'crowd out' duties towards people with whom we do not share any special relationship, or 


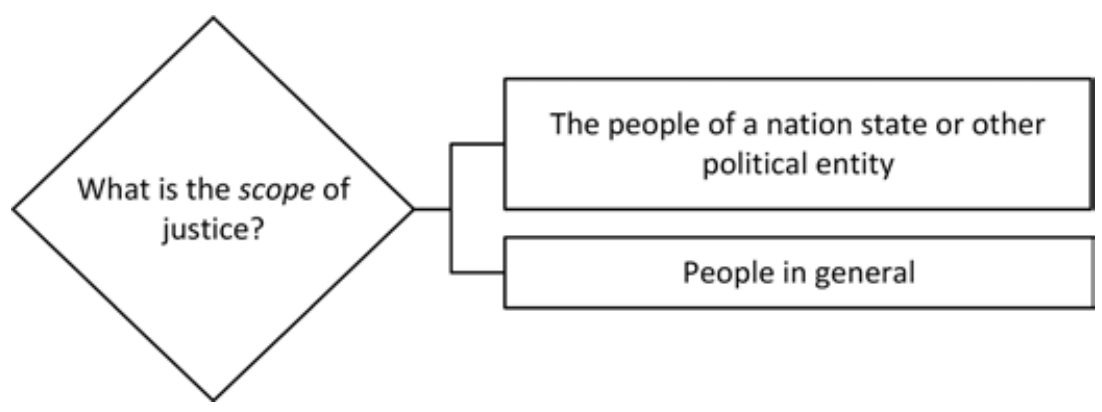

Figure 2.4 The scope of justice

that there are no obligations of justice beyond our communal ties (MacIntyre 1984; Kleingeld and Brown 2019).

There is a vigorous recent debate about whether there are in fact global institutions that entail cosmopolitan principles of distributive justice on Rawlsian grounds. 'Right institutionalist' theorists, as Michael Blake and Patrick Taylor Smith (2015) label them, deny that such global institutions exist. Consequently, they sharply distinguish between national and international justice on Rawlsian grounds, leading them towards an anti-cosmopolitan stance that severely limits distributive obligations to foreigners (Nagel 2005). 'Left institutionalists' agree with right institutionalists that demands of justice are triggered only when we participate in shared institutions, but argue that the institutions of international politics and trade are sufficient to trigger robust distributive obligations, leading them towards a cosmopolitan stance (Cohen and Sabel 2006; Moellendorf 2011; Blake and Smith 2015).

We turn finally to a debate not about the scope of justice, but about how best to realize it, if its scope is cosmopolitan. Institutional or political cosmopolitans claim that justice requires the establishment of new global institutions, something like a world government. Statist cosmopolitans on the other hand claim that an (adjusted) Westphalian system of states can institutionalize cosmopolitan justice. Most moral cosmopolitans can be located somewhere in between these two extremes (see Kleingeld and Brown 2019).

\subsection{CONCLUSION}

Political philosophy gives us a framework for thinking through normative questions of justice, and a wealth of competing conceptions of justice. One fundamental issue that we have encountered is that much philosophical thought about justice has been primarily concerned with questions of the (re)distribution of primary goods. The liberal contractualist tradition still largely affirms 
that paradigm today. Traditionally, the liberal mainstream has been countered by a conservative and communitarian camp, according to which claims of justice should be founded not in abstract understandings of the rational subject, but in concrete understandings of rich moral-political traditions.

In contrast, republican and (deliberatively) democratic political theories put neither the individual rational subject nor the embedded community member centre stage; for them justice is understood as the just ordering of politico-legal institutions that enable citizens to effectively claim civil, political and social rights in diverse societies. Although that same argument could be made from within John Rawls's doctrine of political liberalism, there is an important difference in focus between liberal theories that put individual liberties, including political ones, centre stage in thinking through matters of justice, and those that put the agency of citizens of a shared political system centre stage.

We have given a sampling of some very different views that have arisen in philosophical theorizing about justice; vigorous debates about many of these issues continue. The astute reader may conclude that philosophical reasoning about justice leaves us with more questions than answers. But that may be exactly the point.

\section{NOTE}

1. This chapter draws on material previously published in ETHOS report D2.1 by Rippon et al. (2018). For feedback on previous drafts or parts of this material we would like to thank Jelena Belic, Janos Kis, Eva Kittay, Trudie Knijn, Dorota Lepianka, Zoltán Miklósi, Andrés Moles, Frank Vandenbroucke and Sybe de Vries, and the European Commission's experts Theo Gavrielides and Monique Ischi.

\section{REFERENCES}

Anderson, Elizabeth (1999), 'What is the point of equality?', Ethics, 109 (2), 287-337.

Anderson, Elizabeth (2012), 'Equality', in David Estlund (ed.), Oxford Handbook of Political Philosophy, Oxford: Oxford University Press, pp. 40-58.

Apel, Karl-Otto (1976), Towards a Transformation of Philosophy, reprinted in 1998, Milwaukee, MI: Marquette University Press.

Aristotle (c. 350 BC), Politics, trans. Ernest Barker (1995), revised by R.F. Stalley, The Politics of Aristotle, Oxford: Oxford University Press.

Arneson, Richard (1989), 'Equality and equal opportunity for welfare', Philosophical Studies, 56 (1), 77-93.

Bentham, Jeremy (1789), An Introduction to the Principles of Morals and Legislation, reprinted in J.H. Burns and H.L.A. Hart (eds) (1970), London: The Athlone Press.

Berlin, Isaiah (1958), 'Two concepts of liberty', reprinted in Henry Hardy (ed.) (2002), Liberty, Oxford and New York: Oxford University Press, pp. 166-217.

Blake, Michael and Patrick Taylor Smith (2015), 'International distributive justice', in Edward N. Zalta (ed.), The Stanford Encyclopedia of Philosophy (Spring 
2015 edition), available at https://plato.stanford.edu/archives/spr2015/entries/ international-justice.

Burke, Edmund (1790), Reflections on the Revolution in France, reprinted in J.G.A. Pocock (ed.) (1987), Cambridge, MA: Hackett.

Caney, Simon (2005), Justice Beyond Borders, Oxford: Oxford University Press.

Cohen, G.A. (1989), 'On the currency of egalitarian justice', Ethics, 99 (4), 906-44.

Cohen, G.A. (1997), 'Where the action is: on the site of distributive justice', Philosophy \& Public Affairs, 26 (1), 3-30.

Cohen, Joshua and Charles Sabel (2006), 'Extram republicam nulla justitia?', Philosophy and Public Affairs, 34 (2), 147-75.

Constant, Benjamin (1819), 'The liberty of the ancients compared with that of the moderns', reprinted in Biancamaria Fontana (ed.) (1988), The Political Writings of Benjamin Constant, Cambridge: Cambridge University Press, pp. 309-28.

Dworkin, Ronald (1981), 'What is equality? Part I: equality of resources', Philosophy \& Public Affairs, 10 (4), 283-345.

Dworkin, Ronald (2011), Justice for Hedgehogs, Cambridge, MA: Harvard University Press.

Estlund, David (2005), 'Political authority and the tyranny of non-consent', Philosophical Issues, 15 (1), 351-67.

Forst, Rainer (2011), The Right to Justification: Elements of a Constructivist Theory of Justice, New York: Columbia University Press.

Frankfurt, Harry (1987), 'Equality as a moral ideal', Ethics, 98 (1), 21-42.

Fraser, Nancy (1995), 'From redistribution to recognition? Dilemmas of justice in a “post-socialist" age', New Left Review, I (212), 68-93.

Fraser, Nancy (1996), 'Social justice in the age of identity politics: redistribution, recognition and participation', The Tanner Lectures on Human Values, Stanford University.

Fraser, Nancy (2008), Scales of Justice: Reimagining Political Space in a Globalizing World, New York: Columbia University Press.

Gauthier, David (1986), Morals by Agreement, Oxford: Oxford University Press.

Habermas, Jürgen (1981), Theory of Communicative Action, Vol. 1\&2, reprinted in 1984/7, Boston, MA: MIT Press.

Habermas, Jürgen (1992), Between Facts and Norms, reprinted in 1998, Boston, MA: MIT Press.

Hegel, Georg Wilhelm Friedrich (1821), Elements of the Philosophy of Right, reprinted in 1991, Cambridge: Cambridge University Press.

Held, Virginia (2006), The Ethics of Care: Personal, Political, and Global, Oxford: Oxford University Press.

Hobbes, Thomas (1651), Leviathan, reprinted in Edwin Curley (ed.) (1994), Indianapolis, IN: Hackett.

Honneth, Axel (1995), The Struggle for Recognition: The Moral Grammar of Social Conflicts, trans. Joel Anderson, Cambridge, MA: MIT Press.

Honneth, Axel (2014), Freedom's Rights: The Social Foundations of Democratic Life, New York: Columbia University Press.

Hume, David (1739-40), A Treatise of Human Nature, reprinted in L.A. Selby-Bigge (ed.) (1975), 2nd edn, revised by P.H. Nidditch, Oxford: Clarendon Press.

Kant, Immanuel (1785), 'Grounding for the metaphysics of morals', in Immanuel Kant, Ethical Philosophy, trans. James W. Ellington (1983), Indianapolis, IN: Hackett.

Kittay, Eva Feder (1999), Love's Labor: Essays on Women, Equality, and Dependency, New York: Routledge. 
Kleingeld, Pauline and Eric Brown (2019), 'Cosmopolitanism', in The Stanford Encyclopedia of Philosophy (Winter 2019 edition), in Edward N. Zalta (ed.), available at https://plato.stanford.edu/archives/win2019/entries/cosmopolitanism/.

Klosko, George (1987), 'The principle of fairness and political obligation', Ethics, 97 (2), 353-62.

Kymlicka, Will (1995), Multicultural Citizenship, Oxford: Oxford University Press.

Locke, John (1689), Two Treatises of Government, reprinted in Peter Laslett (ed.) (1988), Cambridge: Cambridge University Press.

Machiavelli, Niccolò (1532), The Prince, reprinted in 1989, Cambridge: Cambridge University Press.

MacIntyre, Alasdair (1984), 'Is patriotism a virtue?', The Lindley Lecture at the University of Kansas, Lawrence, KS: The University of Kansas Press.

Mill, John Stuart (1861), Considerations on Representative Government, reprinted in 1991, Buffalo, NY: Prometheus Books.

Moellendorf, Darrel (2011), 'Cosmopolitanism and compatriot duties', The Monist, 94 (4), 535-54.

Mouffe, Chantal (2000), The Democratic Paradox, London and New York: Verso.

Nagel, Thomas (2005), 'The problem of global justice', Philosophy \& Public Affairs, 33 (3), 113-47.

Nielsen, Kai (1979), 'Radical egalitarian justice: justice as equality', Social Theory and Practice, 5 (2), 209-26.

Nietzsche, Friedrich W. (1886), Beyond Good and Evil: Prelude to a Philosophy of the Future, reprinted in 1990, London: Penguin Books.

Nozick, Robert (1974), Anarchy, State and Utopia, Oxford: Basil Blackwell.

Nussbaum, Martha C. (2001), Women and Human Development: The Capabilities Approach, Cambridge: Cambridge University Press.

Okin, Susan Moller (1991), 'Gender, the public, and the private', in Anne Phillips (ed.), Feminism and Politics, Oxford and New York: Oxford University Press, pp. 116-41.

Parfit, Derek (1997), 'Equality and priority', Ratio, 10 (3), 202-21.

Pateman, Carole (1989), The Disorder of Women: Democracy, Feminism, and Political Theory, Stanford, CA: Stanford University Press/Cambridge University Press.

Pettit, Philip (1997), Republicanism: A Theory of Freedom and Government, Oxford: Oxford University Press.

Plato (c. 390 BC), Gorgias, reprinted in 1979, Oxford and New York: Clarendon Press and Oxford University Press.

Plato (c. 380 BC), Republic, reprinted in 1992, Indianapolis, IN: Hackett.

Rawls, John (1993), Political Liberalism, New York: Columbia University Press.

Rawls, John (1999), A Theory of Justice: Revised Edition, Cambridge, MA: Belknap Press (originally published in 1971).

Rawls, John (2003), Justice as Fairness: A Restatement, Cambridge, MA: Harvard University Press.

Raz, Joseph (1986), The Morality of Freedom, Oxford: Oxford University Press.

Rippon, Simon, Tom Theuns, Sem de Maagt, Miklós Zala and Bert van den Brink (2018), 'Report on the European heritage of philosophical theorizing about justice', ETHOS report D2.1, accessed 9 August 2018 at https://www.ethos-europe.eu/.

Rousseau, Jean-Jacques (1997), The Social Contract and Other Later Political Writings, Cambridge: Cambridge University Press (originally published in 1762).

Scanlon, T.M. (1998), What We Owe to Each Other, Cambridge, MA: Harvard University Press. 
Scheffler, Samuel (2001), Boundaries and Allegiances: Problems of Justice and Responsibility in Liberal Thought, Oxford: Oxford University Press.

Sen, Amartya K. (1999), Development as Freedom, Oxford: Oxford University Press.

Skinner, Quentin (1998), Liberty before Liberalism, Cambridge: Cambridge University Press.

Taylor, Charles (1989), Sources of the Self, Cambridge, MA: Cambridge University Press.

Taylor, Charles (1992), 'The politics of recognition', in Amy Gutmann (ed.), Multiculturalism: Examining the Politics of Recognition, Princeton, NJ: Princeton University Press, pp. 25-73.

Walzer, Michael (1983), Spheres of Justice: A Defense of Pluralism and Equality, New York: Basic Books.

Wolff, Robert Paul (1970), In Defense of Anarchism, New York: Harper and Row.

Wolff, Jonathan (1998), 'Fairness, respect, and the egalitarian ethos', Philosophy \& Public Affairs, 27 (2), 97-122.

Young, Iris Marion (1990), Justice and the Politics of Difference, Princeton, NJ: Princeton University Press. 